\title{
Engineering Education Outside the Classroom: Engagement in Professional Societies
}

\author{
Dr. Achille Messac, Mississippi State University \\ Dr. James N Warnock, Mississippi State University
}

James Warnock is the Interim Associate Dean for Undergraduate Studies in the Bagley College of Engineering at Mississippi State University. His background is in biomedical engineering and he has been a big proponent of self-directed learning and active learning in his classes and was the first person to introduce problem-based learning in the department of agricultural and biological engineering at MSU. James is also the Adjunct Director for training and instruction in the professional services department at ABET. In this role, Warnock oversees the development, planning, production and implementation of the ABET Program Assessment Workshops, IDEAL and the assessment webinar series. He also directs activities related to the workshop facilitator training and professional development.

\section{Dr. Masoud Rais-Rohani, Mississippi State University}

Masoud Rais-Rohani is Associate Dean for Research and Graduate Studies and Professor of Aerospace Engineering in the Bagley College of Engineering at Mississippi State University (MSU). He received his $\mathrm{BS}$ and MS degrees from MSU and $\mathrm{PhD}$ from Virginia Tech, all in aerospace engineering.

He has integrated both computer-based and experiential-learning activities into multiple engineering courses including the senior-level Aerospace Structural Design. More recently, he investigated the use of Emporium model in redesign of the introductory engineering mechanics course. 


\title{
Engineering Education Outside the Classroom: Engagement of Professional Societies
}

\begin{abstract}
To increase participation in professional society activities and promote extracurricular professional growth, the College of Engineering at a major research university in the southeast US introduced a college-wide technical society initiative in fall 2013. The purpose of the initiative was to encourage student integration in their disciplines and to promote professional development through active participation in society events. Overall, the college observed membership in technical societies increase from $19.5 \%$ to $82 \%$ and $33 \%$ to $96 \%$ at the undergraduate and graduate levels, respectively, with a combined membership of $83 \%$ for all eligible (i.e., full-time) students. This was an increase from $21 \%$ prior to the initiative. Detailed description of the technical society initiative and the rationale for its implementation is presented. Although it is too soon to offer an in-depth assessment of the full impact of this initiative, the early indications point to the growing interest on the part of the undergraduate students to seek greater involvement in technical society activities.
\end{abstract}

\section{Motivation for Engagement of Technical Societies}

Towards the middle of the $20^{\text {th }}$ century, engineering education trends began to shift heavily toward engineering science and theory with less emphasis on engineering practice and application. This shift in emphasis led to the growing acceptance that many engineering graduates were not adequately prepared for the workforce, and companies needed to spend additional time and resources on supplemental professional development. The engineering industry started to recognize the deficiency in undergraduate education in the early 1990's and responded most notably through Boeing's list of "Desired Attributes of an Engineer" 1 . ABET responded to the needs of industry and, in 1996, the Engineering Accreditation Commission approved the student learning outcomes for the Engineering Criteria 2000. The eleven student outcomes, commonly referred to as " $a$ thru $k$ ", are comprised of six technical skills and five professional skills ${ }^{2}$. The National Academy of Engineering developed a similar list of attributes for engineers that included additional skills such as leadership and creativity ${ }^{3}$. Thus, the $21^{\text {st }}$ century engineer should be someone with a sound understanding of engineering fundamentals, have a systems approach to engineering design and problem solving, a natural curiosity and desire for continuous learning and an appreciation of globalization, ethical responsibility and diversity.

The challenge that many educators have faced is how to teach students many of the professional skills. The traditional classroom setting may not easily lend itself to effective training of outcomes such as life-long learning, ethical and professional responsibility, or understanding the global context of engineering solutions. Therefore, it becomes necessary to look beyond the classroom for the means to adequately prepare future graduates. Students develop their knowledge and skill over time, and it is the cumulative result of the curricular path they follow (i.e. the courses they take), the pedagogies employed by their instructors, and their out-of-class experiences ${ }^{4}$, that shape their professional future. Out-of-class experiences may include co-ops, internships, research experiences and involvement in student societies. While there is general 
agreement that co-ops, internships and research experiences all enable students to develop their technical skills, little consideration has been given to how participation in technical societies can help students in their professional development.

Engineering professional societies play an important role in the educational experience of students. Participation in these societies provides an opportunity for students to reinforce professional skills and behaviors, including their recognition of the need for life-long learning and an understanding of ethical and professional responsibility, and an appreciation for the global context. A key benefit is their early exposure to their profession that is beyond what they receive in the classroom or in summer employment. However, very few students take advantage of the pertinent resources, or appreciate the importance of professional society engagement, until after graduation.

To increase participation in professional society activities, we introduced a college-wide technical society initiative. Through this initiative, the college covers the cost of membership for all full-time students, including both new memberships and renewals. The purpose of the initiative is to encourage student integration in their discipline and promote professional development through active participation in society events.

Membership in technical societies has numerous benefits for students. First, students have access to more professional development opportunities. Most notably is the prospect of attending national and regional society meetings, reinforcing their recognition for the need to be life-long learners and providing networking opportunities with potential employers and graduate schools. Second, student membership is required for those wishing to participate in many of the competitions sponsored by technical societies. Examples include the ASCE concrete canoe and steel bridge competitions, and the ASME Human Powered Vehicle competition. Participation in these competitions helps reinforce students' teamwork skills, problem solving ability and communication. Additionally, through participation in student chapter meetings, students will develop cohorts and departmental pride, which is expected to increase student success and retention, especially at the first-year level. We also address the all-important financing issue.

\section{Strategy}

The college is comprised of eight departments, housing 10 ABET accredited undergraduate programs and 22 graduate programs. For logistical reasons, only a single technical society was selected for each department. Details of the departments, degree programs and technical society are presented in Table 1.

Table 1: Departments within the college of engineering, degrees offered and the technical society selected for the college-wide initiative

\begin{tabular}{lll}
\hline Department & Degrees Offered* & Technical Society \\
\hline & BS - Aerospace Engineering & $\begin{array}{l}\text { American Institute of Aeronautics } \\
\text { and Astronautics } \\
\text { (AIAA) }\end{array}$ \\
Agrospace Engineering & MS - Aerospace Engineering \\
Engineering & BS - Biological Engineering & $\begin{array}{l}\text { Institute of Biological Engineers } \\
\text { (IBE) }\end{array}$ \\
\hline
\end{tabular}




\begin{tabular}{|c|c|c|}
\hline Department & Degrees Offered* & Technical Society \\
\hline & $\begin{array}{l}\text { MS - Biomedical Engineering } \\
\mathrm{PhD} \text { - Biomedical Engineering }\end{array}$ & \\
\hline Chemical Engineering & $\begin{array}{l}\text { BS - Chemical Engineering } \\
\text { MS - Chemical Engineering }\end{array}$ & $\begin{array}{l}\text { American Institute of Chemical } \\
\text { Engineering } \\
\text { (AIChE) }\end{array}$ \\
\hline $\begin{array}{l}\text { Civil \& Environmental } \\
\text { Engineering }\end{array}$ & $\begin{array}{l}\text { BS - Civil Engineering } \\
\text { MS - Civil Engineering }\end{array}$ & $\begin{array}{l}\text { American Society of Civil } \\
\text { Engineering } \\
\text { (ASCE) }\end{array}$ \\
\hline $\begin{array}{l}\text { Computer Science \& } \\
\text { Engineering }\end{array}$ & $\begin{array}{l}\text { BS - Computer Science } \\
\text { BS - Software Engineering } \\
\text { MS - Computer Science } \\
\text { MS - Computational Engineering } \\
\mathrm{PhD} \text { - Computer Science } \\
\mathrm{PhD} \text { - Computational } \\
\text { Engineering }\end{array}$ & $\begin{array}{l}\text { Association for Computational } \\
\text { Machinery } \\
\text { (ACM) }\end{array}$ \\
\hline $\begin{array}{l}\text { Electrical \& Computer } \\
\text { Engineering }\end{array}$ & $\begin{array}{l}\text { BS - Electrical Engineering } \\
\text { BS - Computer Engineering } \\
\text { MS - Electrical \& Computer } \\
\text { Engineering } \\
\text { PhD - Electrical \& Computer } \\
\text { Engineering }\end{array}$ & $\begin{array}{l}\text { Institute for Electrical and } \\
\text { Electronics Engineers } \\
\text { (IEEE) }\end{array}$ \\
\hline $\begin{array}{l}\text { Industrial \& Systems } \\
\text { Engineering }\end{array}$ & $\begin{array}{l}\mathrm{BS} \text { - Industrial Engineering } \\
\mathrm{MS} \text { - Industrial Engineering } \\
\mathrm{PhD} \text { - Industrial and Systems } \\
\text { Engineering }\end{array}$ & $\begin{array}{l}\text { Institute of Industrial Engineers } \\
\text { (IIE) }\end{array}$ \\
\hline Mechanical Engineering & $\begin{array}{l}\text { BS - Mechanical Engineering } \\
\text { MS - Mechanical Engineering }\end{array}$ & $\begin{array}{l}\text { American Society of Mechanical } \\
\text { Engineers } \\
\text { (ASME) }\end{array}$ \\
\hline
\end{tabular}

* A PhD in engineering is offered through the college of engineering with a concentration in any of the following areas: Aerospace Engineering, Applied Physics, Biological Engineering, Chemical Engineering, Civil Engineering, or Mechanical Engineering. Graduate students with a concentration in Applied Physics were offered membership with the American Physical Society (APS).

All full-time students in the college of engineering were eligible to apply for membership in their technical society through the college initiative. Overall, the college observed membership in technical societies increase from $19.5 \%$ from the previous year to $82 \%$ and $33 \%$ to $96 \%$ at the undergraduate and graduate levels, respectively, with a combined membership of $83 \%$ for all eligible students, up from $21 \%$ the previous year. The percentage of students joining their professional society for each department is shown in Figure 1. 


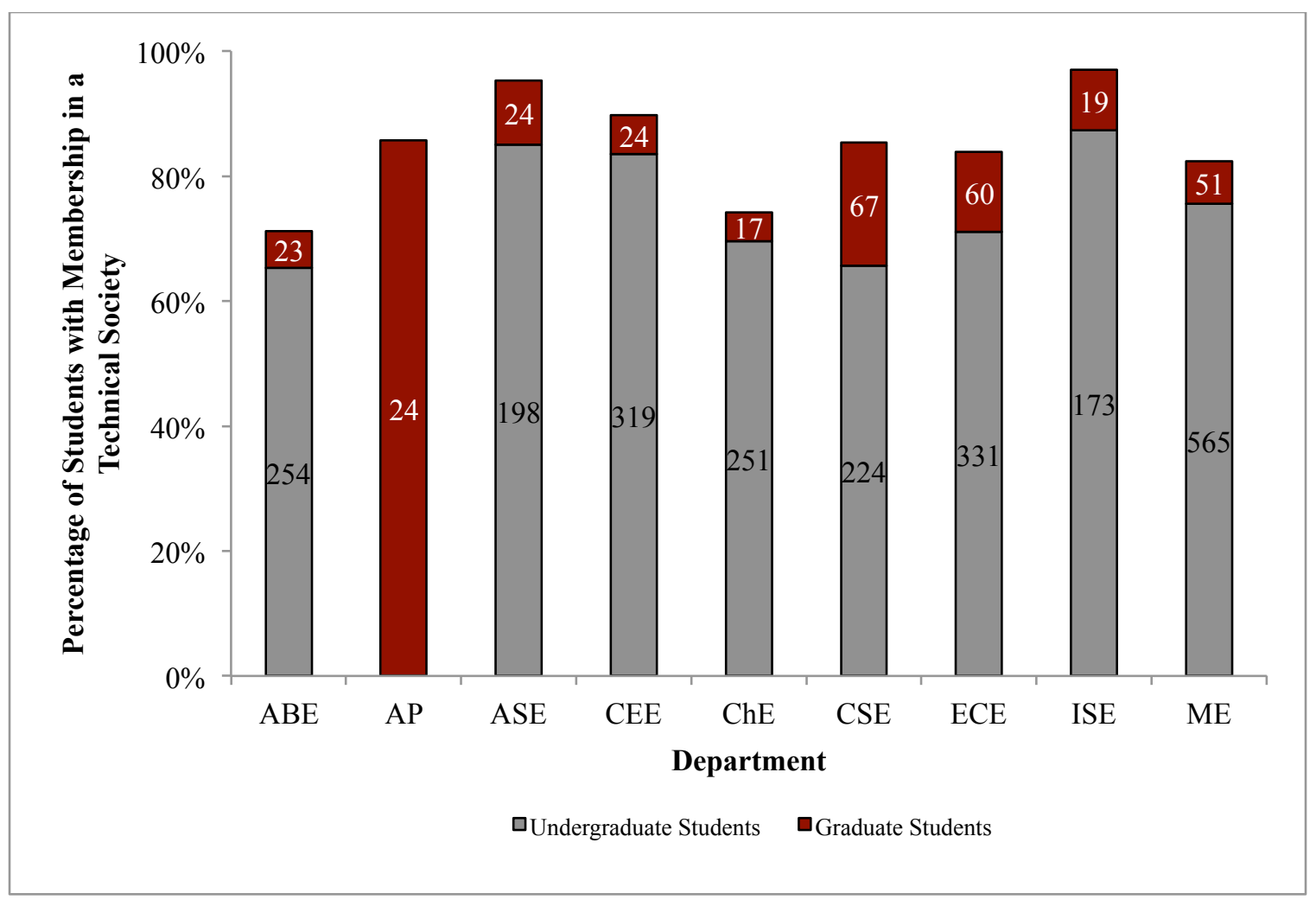

Figure 1: Number of students joining their technical society as a percentage of the total number of students in the department. Values depict the actual number of student members. ABE = Agricultural \& Biological Engineering; AP = Applied Physics (PhD program only); ASE = Aerospace Engineering; $C E E=$ Civil \& Environmental Engineering; $C h E=$ Chemical Engineering; $C S E=$ Computer Science \& Engineering; ECE = Electrical and Computer Engineering; ISE = Industrial \& Systems Engineering; $M E=$ Mechanical Engineering.

At least $70 \%$ of the students in each department participated in the Technical Society Initiative and became members of their society. Aerospace Engineering and Industrial \& Systems Engineering had participation rates in excess of $95 \%$ of students. In the previous year, student memberships were significantly lower with the highest combined rate of participation in Industrial \& Systems Engineering (34\%). Figure 2 shows the increase in student memberships between fall 2012 and fall 2013, when the initiative was introduced. 


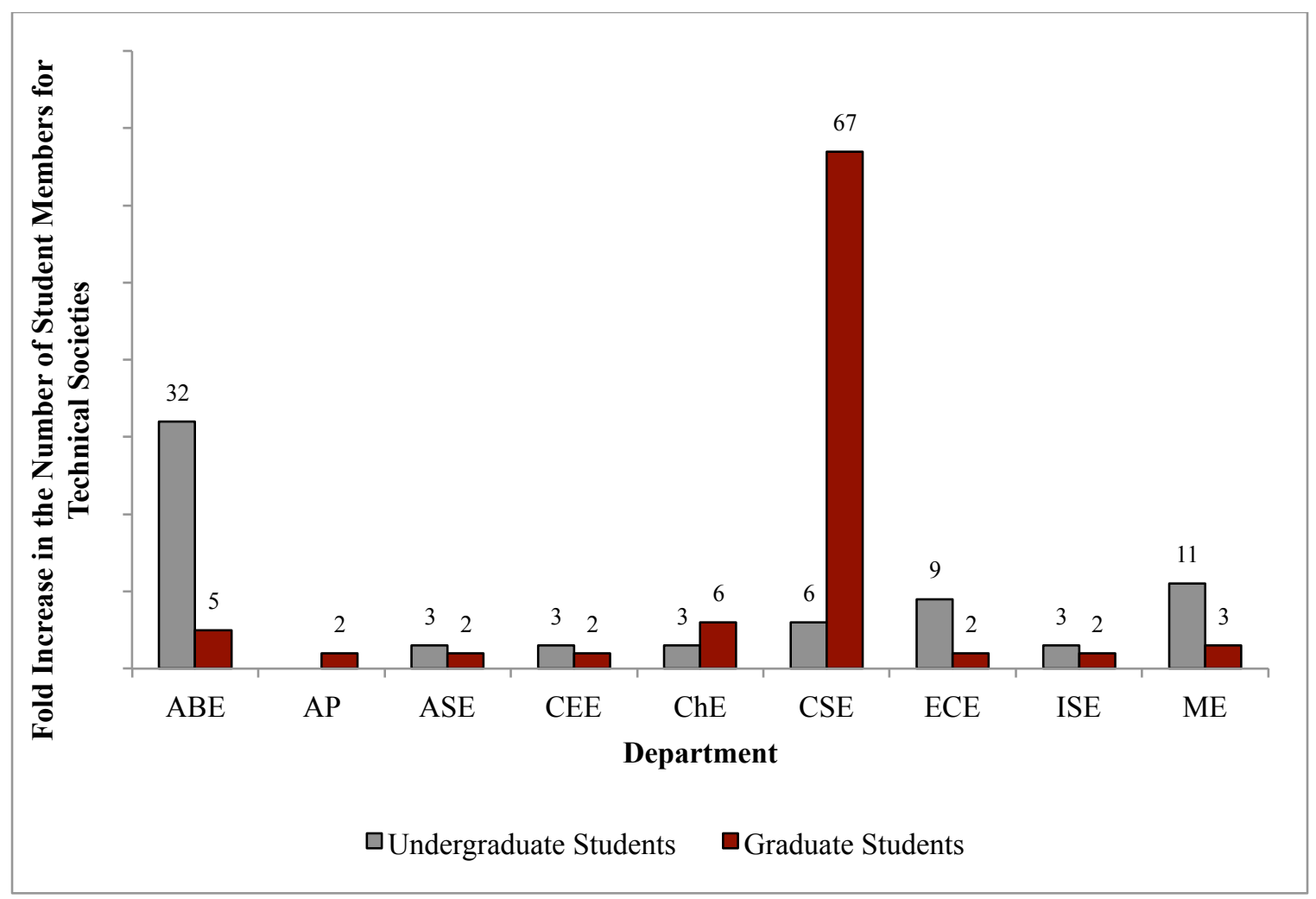

Figure 2: Fold increase in the number of student members for technical societies in fall 2013 for each department at the undergraduate and graduate level, relative to student members in fall 2012.

All undergraduate programs saw at least a 3-fold increase in the number of student members for their respective society. ABE had by far the largest increase in the number of student members, with a 32-fold change between fall 2012 and fall 2013. Similarly, graduate programs across the college saw at least a 2-fold increase in student memberships. CSE saw a 67-fold increase in student membership at the graduate level; the number of student members increased from one to 67 after the introduction of the initiative. The biggest increases were generally seen at the undergraduate level, with the exception of ChE and CSE. Both of these departments had smaller numbers of graduate student members than undergraduate student members prior to the initiative.

To make students aware of the Technical Society Initiative, the program was highly publicized on the college website. Additionally, the Dean sent a letter to all faculty via email explaining the initiative. Consequently, faculty promoted the endeavor through email and in-class announcements.

\section{Activities}

Membership in technical societies potentially has numerous benefits for students. However, membership alone will not necessarily benefit the students. Rather, it is the level of participation that will likely have meaningful impact. To promote participation, several activities are planned, all aimed at the professional development of the students. 
Each of the student chapters has a faculty mentor. New student officers are elected in the spring semester and begin their term in the fall. To help prepare the student officers for their responsibilities, the college will provide training for officers and the faculty mentors at the end of the spring semester. The training will include a planning session where officers will formalize their goals for the year, plan events for the fall and spring semester, identify stakeholders to include in the chapter, and the process to engage the student members in the planned activities. Officers will be required to prepare a budget and include plans on how to fund activities. Each department has its own characteristics and resource availability; therefore, each will be encouraged to develop its own activities. The college will not prescribe a list of events for departments to implement, but will have a few centralized activities.

The college of engineering will promote activities with the most potential to impact students. Of these, participation in regional, national and international meetings will be of highest priority. Participation in these meetings demonstrates to students the importance of life-long learning and shows how their knowledge should continue to increase after graduation. These activities will provide an opportunity for the students to be exposed to the array of research being conducted across the country and across the world; and provide them an opportunity to experience the different and similar challenges faced by international researchers. This exposure reinforces the students' appreciation for the global context of engineering practice. Additionally, professional society meetings provide an opportunity for students to network with professionals, future employers and graduate school recruiters.

Design competitions are a way of enabling students to develop their teamwork skills, engineering skills, and communication skills, and an effective means of creating a sense of community within the cohort. Moreover, because design competitions are conducted outside of the classroom or a course, students are more likely to develop intellectual autonomy because there is not an instructor to whom they can turn if they have questions. Instead, they have to research the information by themselves in a relatively unstructured environment. Student chapters will be encouraged to participate in two different types of design competitions; internal competitions where the teams compete among different departments/societies within the college and external competitions where teams compete against other student chapters from different universities. Two internal competitions will be organized each academic year. The first will be during the presemester engineering convocation and will be a way for student chapters to engage incoming freshmen before classes start. The second internal design competition will be integrated into the activities of engineering week (E-week) in the spring. E-week has varying levels of participation across the college, so it is anticipated that coordinating activities through the student chapters and incorporating a design competition will generate greater interest and increase student involvement. These internal competitions will have the indirect advantage of increasing their identification with, and connection to, their respective departments. These activities will also allow the students to develop an engineering identity and will promote their overall success, resulting in higher retention rates.

External competitions have the benefit of allowing students to develop their technical skills, as well as their professional skills, in areas that are more specific to their respective technical specialties. Examples of external competitions that students are currently involved with include 
the ASCE concrete canoe and steel bridge competitions, and the ASME Human Powered Vehicle competition. Participation in these competitions helps reinforce students' teamwork skills, problem solving ability and communication. Student membership is required for those wanting to participate in many of the competitions sponsored by technical societies.

Finally, technical societies offer several resources to members that can be used in class assignments. Departments with high membership levels $(>90 \%)$ have incorporated resources such as webinars, trade journals and conference archives into several course assignments throughout their curricula. This allows students to develop their self-directed learning skills and have access to the most recent research data.

\section{Student Learning Outcomes and Performance Indicators}

The actual value of the technical society initiative will be measured through the extent that students develop their professional skills. Ultimately, students who actively participate in their student chapters are expected to be well prepared for professional practice. At the end of the first year, students will be assessed on how they have attained the following student outcomes:

1. An ability to function on multidisciplinary teams $(3 \mathrm{~d})$

2. An understanding of professional and ethical responsibility (3f)

3. A recognition of the need for, and an ability to engage in life-long learning (3i)

4. A knowledge of contemporary issues (3j)

The related Engineering Accreditation Commission ABET student outcomes ${ }^{2}$ are shown in parentheses. To effectively measure the attainment of these learning outcomes, several performance indicators have been developed. Performance indicators are specific, measurable statements that articulate the key characteristics of the learning outcome and allow for effective assessment ${ }^{5,6}$. The performance indicators, data source and assessment methods are outlined in Tables 2.

Table 2: Performance indicators to be used in assessing the attainment of student outcomes and determining the value of the technical society initiative to student professional development

\begin{tabular}{|c|c|}
\hline Student Outcome & Performance Indicators \\
\hline Ability to function on a multidisciplinary team & $\begin{array}{l}\text { - Contribute to team meetings } \\
\text { - } \text { Display the necessary work ethic } \\
\text { members } \\
\text { - Explain aspects of a project, process, or } \\
\text { product related to engineering and non- } \\
\text { engineering disciplines }\end{array}$ \\
\hline $\begin{array}{l}\text { An understanding of professional and ethical } \\
\text { responsibility }\end{array}$ & $\begin{array}{l}\text { - Knowledge of the technical society code of } \\
\text { ethics } \\
\text { - Identify different pros and cons for different } \\
\text { courses of action } \\
\text { - Justify their decision to follow a given } \\
\text { course of action }\end{array}$ \\
\hline A recognition of the need for, and an ability to & - Provide information about a specified topic \\
\hline
\end{tabular}




\begin{tabular}{ll}
\hline engage in life-long learning & $\begin{array}{l}\text { from relevant sources } \\
\text { Provide an explanation of all the issues } \\
\text { related to a specified topic }\end{array}$ \\
& $\begin{array}{l}\text { Demonstrates initiative when working on a } \\
\text { project, process or product }\end{array}$ \\
A knowledge of contemporary issues & $\begin{array}{l}\text { Identify contemporary regional, national and } \\
\text { global problems that require an engineering } \\
\text { solution }\end{array}$ \\
& $\begin{array}{l}\text { Propose engineering solutions to regional, } \\
\text { national and global problems }\end{array}$ \\
\hline
\end{tabular}

\section{Assessment}

Tracking and assessing student learning in a single course can be accomplished with relative ease $^{7}$. However, assessing student learning outside of the classroom presents many practical and logistical challenges. Although student organizations have a faculty mentor, the students may function with a high degree of autonomy and the mentor's involvement will vary considerably depending on the specific activities in which the students are engaged. We will employ a convergent mixed methods research plan that uses direct and indirect data collection and analysis with mixing occurring during the final interpretation stage ${ }^{8}$. The simultaneous use of direct and indirect assessments will allow us to best understand how students develop their professional skills as a result of the technical society initiative.

Our direct assessment will be in the form of e-Portfolios. E-Portfolios are a valuable learning and assessment tool and can be a simple and convenient way to record learning goals, achievements and outcomes ${ }^{9}$. They are a digitized collection of artifacts, including demonstrations, resources and accomplishments that represent an individual or organization ${ }^{10}$. The collection will be archived on a website hosted on the college server. It will be essential for the successful integration of e-Portfolios into the technical society initiative to show students how this assessment method is useful in providing feedback to the college about how activities have benefitted their education.

Our indirect assessment will comprise electronic exit surveys and focus groups. The survey will be distributed to all students and will be used to collect data on demographics (gender, ethnicity, class, number of years of society membership) as well as data on the level of participation. Knowing the level of participation is important, as there should be a direct correlation between this metric and the extent to which student outcomes have been achieved. Focus groups will allow targeted a priori analysis to identify elements of the technical society initiative that are of importance to students.

\section{Limitations}

During the implementation of the technical society initiative, we encountered some unforeseen challenges. For logistical reasons, it was decided that only one technical society would be supported for each department. However, several departments offer programs that could have memberships in multiple societies. For example, in the department of agricultural and biological 
engineering there were two professional societies; the Institute of Biological Engineers (IBE) and the American Society for Agricultural and Biological Engineering (ASABE). To further complicate matters, approximately $33 \%$ of graduate students are studying biomedical engineering and expressed a desire to join the Biomedical Engineering Society (BMES). The issue of selecting the most appropriate technical society was also present in Computer Science and Engineering, Computational Engineering, and Electric and Computer Engineering.

A similar but distinct limitation was noted in mechanical engineering; ASME appeared to be the most appropriate technical society for mechanical engineers to join. However, ME has a broad base of disciplines that are not necessarily captured by ASME. In addition to ASME, faculty and students are members of the Society for Automotive Engineers (SAE), ASTM (formerly known as American Society for Testing and Materials and American Foundry Society (AFS). To overcome this limitation, the mechanical engineering department sponsored membership of students in a second technical society if they had first taken advantage of the college technical society initiative. This dual enrollment consequently has provided additional opportunities for students and has given them access to a greater variety of student projects.

The rapid increase in student membership has presented some logistical complications. For most programs, the number of student members has increased by 2- to 3-fold. However, for societies with a greater increase in student numbers, it has been challenging to organize meetings because of student schedules and room capacity. The ASME student chapter, for example, saw a 11-fold increase in membership. This meant their undergraduate membership went from 52 students to 565. The goal of the initiative was not simply to increase membership but to increase participation. Securing a location for this many students to meet at any given time is problematic. Therefore, it has been proposed that the ASME section divide into smaller sections that are easier to manage.

\section{Financing the Students Membership Initiative}

An important aspect of this initiative is its financing. To initiate this initiative, the college provided the funding. However, there are other ways to address this issue in the long term. The first approach to consider is to seek department-wide discounts from respective technical society. They are generally conducive to cooperate with such requests. The second is to seek alumni or corporate sponsorships. Supportive alumni and corporate friends are generally amenable to partially or fully support such student-centric initiatives, either for a given year, or as a named endowment. We have been successful with these approaches.

\section{Concluding Remarks}

In conclusion, the Technical Society Initiative has been successful with a significant number of engineering students becoming members of their professional society. Although it is too soon to draw in-depth conclusions of the full impact of this initiative, we anticipate this initiative will lead to improved development of professional skills and graduates being better prepared for engineering practice. 


\section{References}

1 McMasters, J. H. \& Komerath, N. in 2005 American Society for Engineering Education Annual Conference \& Exposition. (American Society for Engineering Education).

2 ABET. Criteria for Accrediting Engineering Programs; Effective for Reviews During the 2014-2015 Accreditation Cycle, $<$ http://www.abet.org/eac-criteria-2014-2015/> (2014).

3 Clough, G. W. The engineer of 2020: Visions of engineering in the new century. National Academy of Engineering, Washington (2004).

4 Terenzini, P. T., Springer, L., Pascarella, E. T. \& Nora, A. Influences affecting the development of students' critical thinking skills. Research in higher education 36, 23-39 (1995).

5 Felder, R. M. \& Brent, R. Designing and teaching courses to satisfy the ABET engineering criteria. Journal of Engineering Education 92, 7-25 (2003).

6 Besterfield-Sacre, M. et al. Defining the outcomes: A framework for EC-2000. Education, IEEE Transactions on 43, 100-110 (2000).

7 Wickersham, L. E. \& Chambers, S. M. ePORTFOLIOS: USING TECHNOLOGY TO ENHANCE AND ASSESS STUDENT LEARNING. Education 126 (2006).

8 Creswell, J. W. \& Clark, V. L. P. Designing and conducting mixed methods research. (Wiley Online Library, 2007).

9 Stefani, L., Mason, R. \& Pegler, C. The educational potential of e-portfolios: Supporting personal development and reflective learning. (Routledge, 2007).

10 Lorenzo, G. \& Ittelson, J. An overview of e-portfolios. Educause learning initiative 1, 1-27 (2005). 